\title{
Synthesis and Evaluation of Cytotoxic Effects of Amino-ester Derivatives of Natural $\alpha, \beta$-Amyrin Mixture
}

\author{
Mauricio M. Victor, ${ }^{*, a, b}$ Jorge M. David, ${ }^{a, b}$ Marcelo A. S. dos Santos, ${ }^{a, c}$ \\ André L. B. S. Barreiros, ${ }^{d}$ Marizeth L. Barreiros, ${ }^{d}$ Fernanda S. Andrade, ${ }^{d}$ \\ Adriana A. Carvalho, ${ }^{e}$ Maria Claudia S. Luciano, ${ }^{f}$ Manoel O. de Moraes, ${ }^{f}$ \\ Francisco W. A. Barros-Nepomuceno ${ }^{g}$ and Claudia Pessoaf ${ }^{f, h}$
}

\author{
${ }^{a}$ Departamento de Química Orgânica, Instituto de Química, Universidade Federal da Bahia (UFBA) and \\ ${ }^{b}$ Instituto Nacional de Ciência e Tecnologia de Energia e Meio Ambiente, \\ 40170-115 Salvador-BA, Brazil \\ 'Instituto Federal de Educação, Ciência e Tecnologia da Bahia (IFBA), \\ 44096-486 Feira de Santana-BA, Brazil
}

${ }^{d}$ Departamento de Química and ${ }^{e}$ Departamento de Fisiologia, Universidade Federal do Sergipe (UFS), 49000-100 São Cristóvão-SE, Brazil

${ }^{f}$ Núcleo de Pesquisa e Desenvolvimento de Medicamentos (NPDM), Universidade Federal do Ceará (UFC), 60430-275 Fortaleza-CE, Brazil

${ }^{8}$ Universidade da Integração Internacional da Lusofonia Afro-Brasileira (UNILAB), 62785-000 Acarape-CE, Brazil

${ }^{h}$ Fundação Oswaldo Cruz, 60176-032 Fortaleza-CE, Brazil

\begin{abstract}
Natural $\alpha, \beta$-amyrins were isolated from endemic Brazilian Esenbeckia grandiflora Mart., and eight synthetic derivatives were obtained by esterification reactions with bromo acetate, followed by amine treatment. The structures of the all compounds were confirmed by ${ }^{1} \mathrm{H}$ and ${ }^{13} \mathrm{C}$ nuclear magnetic resonance (NMR), Fourier transform infrared (FTIR) and high-resolution mass spectrometry (HRMS) data analysis. The derivatives were screened for cytotoxic activity against human tumor cell-lines PC3 (prostate carcinoma), HCT-116 (colon carcinoma) and HL60 (leukemia). HCT-116 and PC3 cell-lines showed weak tumor growth inhibition (range of 13.9-25.4 and $10.3-28.8 \%$, respectively), but the derivatives presented moderate activity against HL60 (range of 13.6-59.0\%). Diethyl, aniline, morpholine and imidazole moieties presented higher activities (range of $45.9-59.0 \%$ ).
\end{abstract}

Keywords: $\alpha, \beta$-amyrins, pentacyclic triterpenes, Esenbeckia grandiflora, aminoester derivatives, antiproliferative evaluation

\section{Introduction}

Cancer is a generic term for a large group of diseases that can affect any part of the body, being also known by other terms such as malignant tumors and neoplasms. According to WHO (World Health Organization), it accounted 8.2 million deaths worldwide in 2012 (13\% of all deaths) with 14.1 million new cases. ${ }^{1}$ Main risk in cancer treatment is multidrug resistance, when cells lose

*e-mail: mmvictor@ufba.br their sensitivity to chemotherapeutics, leading to intensify the action against cancer by developing and reinforcing of control programmers and to search alternative treatments.

Triterpenes $\alpha$ - and $\beta$-amyrins $(\mathbf{1 a}, \mathbf{b})$ are structural isomers and possess basic skeletons of two different subgroups of pentacyclic terpenoids, known as ursane and oleanane, respectively. ${ }^{2}$ The only structural difference between them appears in the E-ring methyl group position at $\mathrm{C}$-19 ( $\alpha$-amyrin) or $\mathrm{C}$-20 ( $\beta$-amyrin) (Figure 1$)$. These triterpenes and their derivatives are shown to possess a broad spectrum of pharmaceutical and 
biological activities including anti-inflammatory, ${ }^{3-7}$ anti-nociceptive, ${ }^{8}$ insecticidal,,${ }^{9,10}$ anti-depressant, ${ }^{11}$ anti-arthritic, ${ }^{12}$ gastroprotective, ${ }^{13}$ anti-hyperglycemic, ${ }^{14}$ anti-ulcer, ${ }^{15}$ anti-microbial ${ }^{16,17}$ and antiplatelet. ${ }^{18}$

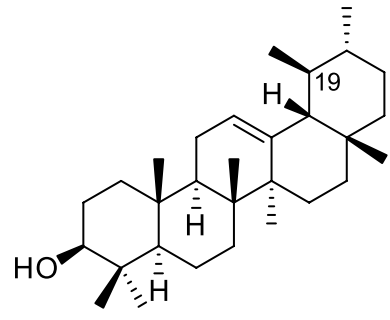

$\alpha$-amyrin (1a)

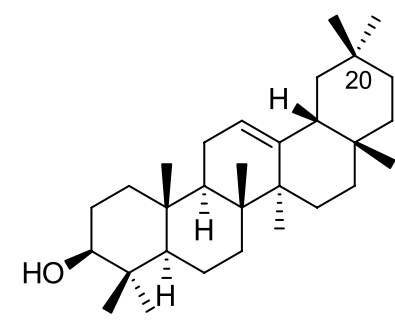

$\beta$-amyrin (1b)
Figure 1. The structures of $\alpha$ - and $\beta$-amyrins.

Although the pentacyclic triterpenes $\alpha, \beta$-amyrins have weak anticancer activity, some investigations of the cytotoxic effects of these compounds have been conducted. For example, $\beta$-amyrin exhibited weak cytotoxic activity in the co-treatment with cisplatin against NTUB1 (bladder) cells. ${ }^{19}$ This component also exhibited weak cytotoxicity against A549 (lung) and HL-60 (leukemia) cancer cell-lines with $\mathrm{IC}_{50}$ values (half maximal inhibitory concentration) of 46.2 and $38.6 \mu \mathrm{M}$, respectively. ${ }^{20}$ Cytotoxic activities of esters of $\alpha, \beta$-amyrins were also screened in four human tumor cell-lines (HL-60; MDAMB-435, breast adenocarcinoma; SF-295, glioblastoma; and HCT-8, colon), being 3-O-carboxymaleinate derivative the only active compound of the series. ${ }^{21}$ Taking into account that ester transformation in C-3 was already performed with success to increase pharmacological activity of pentacyclic triterpenes ( $\alpha, \beta$-amyrins), and due to the fact that the modification of the rings usually requires multistep sequence of chemical manipulations, we decided to synthesize new $\alpha$-amino ester derivatives employing one simple and efficient synthetic route, and evaluate their cytotoxic activity against human cancer cell-lines.

\section{Results and Discussion}

The mixture of triterpenoid $\alpha, \beta$-amyrin $\mathbf{1 a}, \mathbf{b}$ was isolated from leaves of Esenbeckia grandiflora Mart., a Brazilian endemic plant from Rutaceae family (see Experimental section). Detailed ${ }^{1} \mathrm{H}$ nuclear magnetic resonance (NMR) analysis permitted to determinate the mixture at the $1: 1$ ratio of $\alpha$ - and $\beta$-amyrin. The spectra displayed two triplets to $\mathrm{H}-12$ at $\delta 5.14$ of the $\alpha$-amyrin and $\delta 5.19$ of the $\beta$-amyrin, and its integrations showed 0.49:0.51 proportion areas, respectively. All other analytical data were according to literature. ${ }^{2}$
The $\alpha, \beta$-amyrin derivatives 3-9a,b were synthesized by a modified literature procedure previously described (Scheme 1). ${ }^{22}$ Regarding this procedure, acylation of hydroxyl group of C-3 position was performed by treatment of mixture $\mathbf{1 a}, \mathbf{b}$ with bromoacetyl bromide in $\mathrm{CHCl}_{3}$ in the presence of anhydrous $\mathrm{K}_{2} \mathrm{CO}_{3}$ at room temperature for $24 \mathrm{~h}$, affording $\alpha$-bromoacetyl mixture $\mathbf{2 a}, \mathbf{b}$ derivative as a white solid with $85 \%$ yield. The Fourier transform infrared spectra (FTIR) showed absorption band at $1751 \mathrm{~cm}^{-1}$, characteristic of $\mathrm{C}=\mathrm{O}$ stretching of ester, corroborating with the structure of the synthetic product. The comparison of the ${ }^{1} \mathrm{H}$ NMR spectra of the product with the amyrins showed a new signal at $\delta 3.84$ due to the presence of bromoacetyl moiety, and the upshielding of H-3 signal (from $\delta 3.24$ to 4.58 ) confirms the esterification at C-3. The two new signals at $\delta 167.1$ and 28.0 registered in the ${ }^{13} \mathrm{C}$ NMR spectra also assigned the synthesis of $\mathbf{2 a}, \mathbf{b}$. Sequentially, the $\alpha$-bromoester derivatives (2a,b) were submitted to a synthesis of amino-acetyl derivatives by simple treatment of these compounds with amine excess. To our delight, the reaction of $\alpha, \beta$-amyrin derivatives $\mathbf{2 a , b}$ with diethylamine $\mathbf{3}$ in $\mathrm{MeCN}$ afforded a $\mathbf{3 a}, \mathbf{b}$ mixture in $77 \%$ yield after $24 \mathrm{~h}$ as a white solid. The synthesis was corroborated by the ${ }^{1} \mathrm{H}$ NMR spectra analysis: the two signals at $\delta 1.09(6 \mathrm{H}, J 5 \mathrm{~Hz})$ and $2.70(4 \mathrm{H}, J 5 \mathrm{~Hz})$, related to $\mathrm{H}_{2 \mathrm{a}, \mathrm{b}}$ and $\mathrm{H}_{\mathrm{la}, \mathrm{b}}$, respectively, assure the presence of a new diethyl moiety. This same evidence was found in ${ }^{13} \mathrm{C}$ NMR spectra analysis by the two new intense signals at $\delta 47.8$ $\left(\mathrm{C}_{1 \mathrm{a}, \mathrm{b}}\right)$ and $12.4\left(\mathrm{C}_{2 a, \mathrm{~b}}\right)$. In the same way, the aminoacetyl structure was also assured by absorption band of $\mathrm{C}=\mathrm{O}$ stretching at $1732 \mathrm{~cm}^{-1}$ observed in FTIR spectra. The same procedure was successfully applied to other amine derivatives (piperidine $\mathbf{4}$, morpholine $\mathbf{5}$, pyrrolidine $\mathbf{6}$, aniline $\mathbf{7}$ and benzylamine 8), it furnished aminoacetyl derivatives 4-8a,, $\mathbf{b}$ with yields ranging $71-99 \%$. The FTIR spectra of the prepared compounds showed $\mathrm{C}=\mathrm{O}$ stretching due to the aminoacetyl moiety ranging $1724-1746 \mathrm{~cm}^{-1}$. The ${ }^{1} \mathrm{H}$ NMR spectra of piperidine derivatives $(\mathbf{4 a}, \mathbf{b})$ presented new signals at $\delta 2.54\left(4 \mathrm{H}, \mathrm{H}_{2^{\prime}}\right.$, and $\left.\mathrm{H}_{6^{\prime}}\right), 1.55(4 \mathrm{H}$, $\mathrm{H}_{3}$, and $\left.\mathrm{H}_{5^{\prime \prime}}\right)$ and $1.44\left(2 \mathrm{H}, \mathrm{H}_{4^{\prime \prime}}\right)$ when compared with the starting material, while ${ }^{13} \mathrm{C}$ NMR spectra revealed signals at $\delta 60.4\left(\mathrm{C}_{2^{\prime \prime}}\right.$ and $\left.\mathrm{C}_{6^{\prime}}\right), 25.8\left(\mathrm{C}_{3^{\prime \prime}}\right.$ and $\left.\mathrm{C}_{5^{\prime \prime}}\right)$ and $24.0\left(\mathrm{C}_{4^{\prime}}\right)$. These resonances are in accordance with the expected ones for the structure. The NMR spectra of the morpholine derivative $\mathbf{5 a}, \mathbf{b}$ permitted to observe the presence of the oxy and aminomethylene signals at $\delta 2.61\left(4 \mathrm{H}, \mathrm{H}_{2^{\prime \prime}}\right.$ and $\left.\mathrm{H}_{6^{\prime \prime}}\right)$ and $3.76\left(4 \mathrm{H}, \mathrm{H}_{3^{\prime \prime}}\right.$ and $\left.\mathrm{H}_{5^{\prime}}\right)$, respectively, in the ${ }^{1} \mathrm{H}$ NMR spectrum, and at $\delta 66.8\left(\mathrm{C}_{3^{\prime \prime}}\right.$ and $\left.\mathrm{C}_{5^{\prime \prime}}\right)$ and $53.3\left(\mathrm{C}_{2}\right.$, and $\mathrm{C}_{6^{\prime}}$ ), respectively, in the ${ }^{13} \mathrm{C}$ NMR spectra as well. For derivative 6a,b, $\delta 2.86\left(4 \mathrm{H}_{1} \mathrm{H}_{2,}\right.$ and $\left.\mathrm{H}_{5,}\right)$ and $1.91\left(4 \mathrm{H}, \mathrm{H}_{3}\right.$, and $\left.\mathrm{H}_{4^{\prime \prime}}\right)$ in ${ }^{1} \mathrm{H}$ NMR and $\delta 53.6\left(\mathrm{C}_{2^{\prime \prime}}\right.$ and $\left.\mathrm{C}_{5^{\prime \prime}}\right)$ and $24.0\left(\mathrm{C}_{3^{\prime \prime}}\right.$ 
and $\mathrm{C}_{4}$ ) in the ${ }^{13} \mathrm{C}$ NMR assured the pyrrolidine moiety. For derivative 7a,b, new signals appeared at $\delta 6.64\left(2 \mathrm{H}, \mathrm{H}_{2}\right.$ " and $\left.\mathrm{H}_{6^{\prime}}\right), 7.20\left(2 \mathrm{H}, \mathrm{H}_{3^{\prime \prime}}\right.$ and $\left.\mathrm{H}_{5^{\prime \prime}}\right)$ and $6.77\left(1 \mathrm{H}, \mathrm{H}_{4^{\prime \prime}}\right)$ in the ${ }^{1} \mathrm{H}$ NMR spectra, while in the ${ }^{13} \mathrm{C}$ NMR signals appeared at $\delta 113.0\left(\mathrm{C}_{2^{\prime \prime}}\right.$ and $\left.\mathrm{C}_{6^{\prime \prime}}\right), 129.3\left(\mathrm{C}_{3^{\prime \prime}}\right.$ and $\left.\mathrm{C}_{5^{\prime}}\right)$ and $118.2\left(\mathrm{C}_{4^{\prime \prime}}\right)$ due to the aniline moiety. Benzylamine derivative $\mathbf{8 a}, \mathbf{b}$ showed signals in the ${ }^{1} \mathrm{H}$ NMR spectra at $\delta 3.87\left(2 \mathrm{H}, \mathrm{H}_{4}\right.$ ) due to the benzylmethylene hydrogens and the hydrogens of the aromatic ring at $\delta 7.36(5 \mathrm{H})$. These findings were corroborated by the ${ }^{13} \mathrm{C}$ NMR data at $\delta 53.1\left(\mathrm{C}_{4}\right), 138.6$ $\left(\mathrm{C}_{1^{\prime}}\right), 128.5\left(\mathrm{C}_{2^{\prime \prime}}, \mathrm{C}_{3^{\prime \prime}}, \mathrm{C}_{5^{\prime \prime}}\right.$ and $\left.\mathrm{C}_{6^{\prime}}\right)$ and $127.4\left(\mathrm{C}_{4^{\prime \prime}}\right)$. For the imidazole derivative, a slight modification in the synthesis was performed, which required DMF (dimethylformamide) as solvent ${ }^{23}$ to lead $\mathbf{9 a}, \mathbf{b}$ with $54 \%$ of yield. Their syntheses were corroborated by the appearance in the ${ }^{1} \mathrm{H}$ NMR spectra of signals at $\delta 7.53\left(1 \mathrm{H}, \mathrm{H}_{2^{\prime}}\right), 7.11\left(1 \mathrm{H}, \mathrm{H}_{4^{\prime}}\right)$ and $6.96(1 \mathrm{H}$, $\mathrm{H}_{5^{\prime \prime}}$, while ${ }^{13} \mathrm{C}$ NMR spectra showed new signals at $\delta 137.9$ $\left(\mathrm{C}_{2^{\prime \prime}}\right), 129.7\left(\mathrm{C}_{4^{\prime \prime}}\right)$ and $199.9\left(\mathrm{C}_{5^{\prime \prime}}\right)$.

The cytotoxic effects of aminoacetyl derivatives 3-9a,b were evaluated using the MTT (3-(4,5-dimethylthiazol2-yl)-2,5-diphenyltetrazolium bromide) assay. ${ }^{24}$ The compounds were incubated with three human tumor cell-lines (HCT-116, colon; HL-60, leukemia; and PC-3, prostate) at $5 \mu \mathrm{g} \mathrm{mL}-1$ and the percentage reduction in cell viability (RCV) was determined after $72 \mathrm{~h}$. The results presented in Table 1 are useful to carry out a preliminary structure-activity relationship study. Compounds $\mathbf{5 a}, \mathbf{b}$, 6a,b and 9a,b (morpholine, pyrrolidine and imidazole derivatives, respectively) presented medium activity against HCT-116. Compounds 5a,b and $\mathbf{7 a}, \mathbf{b}$ (aniline derivative) showed medium activity against HL-60, while diethylamine and imidazole derivatives (compounds $\mathbf{3 a}, \mathbf{b}$ and $\mathbf{9 a}, \mathbf{b}$, respectively) exhibited high activity against this cell-line. In addition, compounds $\mathbf{2 a , b}$ (bromoacetyl precursor) and $\mathbf{5 a}, \mathbf{b}$ showed low activity against PC-3. Doxorubicin showed high cytotoxic effect against all tested cell-lines being used in this study as positive control of assay and not for the new compounds.

Table 1. Percent reduction in cell viability (RCV) caused by $\alpha, \beta$-amyrin derivatives at single concentration $\left(5 \mu \mathrm{g} \mathrm{mL}^{-1}\right)$ against human tumor cell-lines after $72 \mathrm{~h}$ of incubation using MTT assay

\begin{tabular}{lccc}
\hline & \multicolumn{3}{c}{ RCV $^{\mathrm{a}} \pm$ SEM / \% } \\
\cline { 2 - 4 } Compound & \multicolumn{3}{c}{ Cell-line } \\
\cline { 2 - 4 } & HCT-116 & HL-60 & PC-3 \\
\hline $\mathbf{2 a}, \mathbf{b}$ & $16.44 \pm 0.18$ & $22.90 \pm 5.53$ & $28.77 \pm 6.70$ \\
$\mathbf{3 a}, \mathbf{b}$ & $19.95 \pm 4.26$ & $58.97 \pm 2.14$ & $18.03 \pm 1.56$ \\
$\mathbf{4 a}, \mathbf{b}$ & $12.95 \pm 3.42$ & $15.10 \pm 1.17$ & $12.26 \pm 1.45$ \\
$\mathbf{5 a}, \mathbf{b}$ & $23.31 \pm 0.84$ & $45.88 \pm 1.02$ & $23.40 \pm 2.23$ \\
$\mathbf{6 a}, \mathbf{b}$ & $21.08 \pm 3.55$ & $13.64 \pm 4.58$ & $17.71 \pm 2.68$ \\
$\mathbf{7 a}, \mathbf{b}$ & $13.86 \pm 3.99$ & $46.85 \pm 7.02$ & $10.25 \pm 0.73$ \\
$\mathbf{8 a , b}$ & $16.25 \pm 2.22$ & $31.37 \pm 1.37$ & $13.68 \pm 2.79$ \\
$\mathbf{9 a}, \mathbf{b}$ & $25.38 \pm 1.29$ & $56.82 \pm 1.69$ & $19.45 \pm 2.01$ \\
Dox $^{\mathrm{b}}$ & $84.87 \pm 1.09$ & $96.99 \pm 0.31$ & $87.65 \pm 1.50$ \\
\hline
\end{tabular}

aLow activity: $1 \%<$ RCV\% < 20\%; medium activity: $20 \%<$ RCV\% $<50 \%$; and high activity: $50 \%<\mathrm{RCV} \%<100 \%$. ${ }^{\mathrm{b}}$ Doxorrubicin (Dox) was used as positive control and tested at concentration of $5 \mu \mathrm{g} \mathrm{mL}^{-1}$. SEM: standard error of the mean. Data were obtained from at least three independent experiments performed in triplicate; MTT: 3-(4,5-dimethylthiazol2-yl)-2,5-diphenyltetrazolium bromide. PC3: prostate carcinoma; HCT-116: colon carcinoma; and HL60: leukemia.

These results agree with previous reports of Barros et al.,$^{21}$ in which ester derivatives of $\alpha, \beta$-amyrin mixture demonstrated higher activity against tumor lines of leukemia cells HL-60 than other tested ones (MDAMB-435, melanoma; SF-295, glioblastoma; and HCT-8, colon cancer). However, in that previous study,
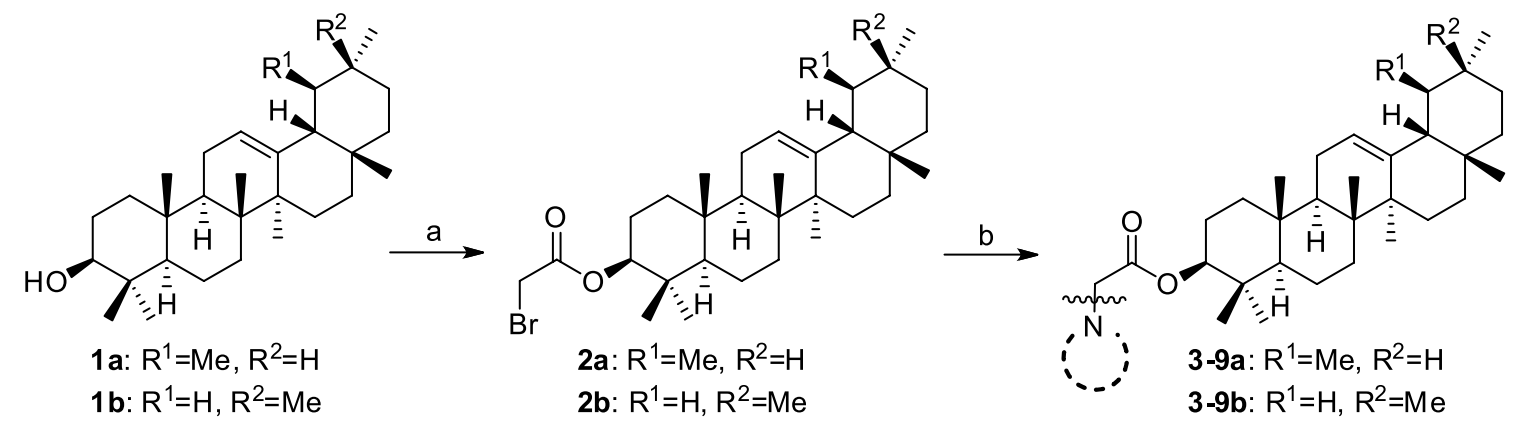

Amines
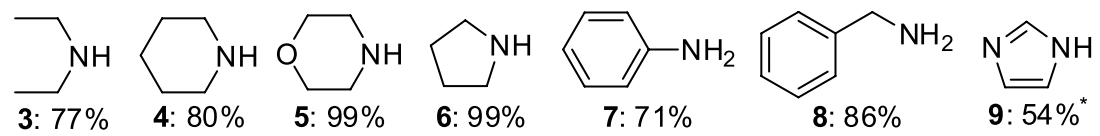

Scheme 1. Reagents and conditions: (a) $\mathrm{BrCH}_{2} \mathrm{COBr}, \mathrm{K}_{2} \mathrm{CO}_{3}, \mathrm{CHCl}_{3}$, room temperature, $24 \mathrm{~h}, 85 \%$, and (b) amine ( 3 equiv.), MeCN or DMF*, room temperature, 24 h, 54-99\%. 
the higher activity of the maleinate derivative attached to carbon 3 was assigned due to the presence of the unsaturation in the lateral chain. In the present study, higher activities were exhibited by diethylamine $\mathbf{3 a}, \mathbf{b}$ and imidazole 9a,b derivatives. While the latter exhibits double bond in the structure, the first does not display. The presence of the nitrogen atom in the side chain generates an electron-rich center of coordination to promote chemical interactions with center deficient in electrons. Nevertheless, all other derivatives with lower activity contain nitrogen in its structure. Also, comparisons on ring sizes (five or six membered) and/or aromaticity in side chain are not conclusive. Free alkyl chains in diethylamine moiety and a second coordination atom in the imidazole ring seem to be the most prominent features of the most active derivatives, although more studies are needed for more conclusive structure-activity relationship.

In order, we tested the compounds in different concentrations (0.05-25 $\mu \mathrm{g} \mathrm{mL}-1)$ against HCT-116 and PC-3 cells by MTT assay in order to determine the concentration able to reduce the number of viable cells by $50 \%\left(\mathrm{RC}_{50}\right)$ after $72 \mathrm{~h}$ of incubation. The results show that none tested compound was active against the human cancer cell-lines used $\left(\mathrm{RC}_{50}>25 \mu \mathrm{g} \mathrm{mL}-1\right.$ ). Doxorrubicin (Dox) (positive control) showed $\mathrm{RC}_{50}$ values from 0.01 (0.08-0.12) and $0.15(0.10-0.21) \mu \mathrm{g} \mathrm{mL}-1$ against HCT-116 and PC-3, respectively.

\section{Conclusions}

In conclusion, a series of novel aminoacetyl $\alpha, \beta$-amyrin derivatives were synthesized and their cytotoxic activities were evaluated against human colon carcinoma HCT-116, human acute promyelocytic leukemia HL-60 and human prostate adenocarcinoma PC-3 tumor cell-line using an in vitro cytotoxicity assay. Among these compounds, diethylamine and imidazole derivatives (compounds 3a,b and $\mathbf{9 a}, \mathbf{b}$, respectively) displayed the most potent cytotoxic activity and were found to be more effective against HL-60. These preliminary results showed that the synthesis of new derivatives is required to improve anticancer activity in vitro of the tested compounds.

\section{Experimental}

\section{General experimental procedures}

All reagents were purchased from Sigma-Aldrich and Acros Chemicals and used without further purification. $\alpha, \beta$-Amyrin mixture was previously isolated from Eriope blanchetti (Lamiaceae). Chloroform was refluxed with $\mathrm{CaH}_{2}$ and distilled prior to use. Acetonitrile was used in HPLC grade. $N, N$-Dimethylformamide (DMF) was treated with $\mathrm{CaH}_{2}$, distilled and stored on $4 \mathrm{~A}$ molecular sieves. Aniline, benzylamine, morpholine, piperidine and pyrrolidine were distilled priori to use. All reactions were performed under argon atmosphere. Analytical thin layer chromatography (TLC) was performed on E. Merck TLC plates pre-coated with silica gel $60 \mathrm{~F}_{254}$ ( $250 \mu \mathrm{m}$ thickness). The visualization was accomplished using UV light and potassium permanganate solution. Column chromatography (CC) was performed on silica gel (60-120 ̊̊ pore size). The melting points were uncorrected and determined on a MQAPF-302 apparatus. FTIR spectra were measured using a Shimadzu IRAffinity-1S spectrophotometer. NMR spectra were recorded on Varian spectrometer Inova-500 in deuterated solvents. Electrospray high-resolution mass spectra (ESI-HRMS) were obtained using Agilent 6550 Q-TOF MS instrument in the positive mode.

Plant material: collection and identification of Esenbeckia grandiflora

Leaves of Esenbeckia grandiflora were collected at the surroundings of the city of Barra dos Coqueiros, Sergipe State, Brazil (1048'20'S; 36 58'10'W). The specimen was identified by Dr Milton Groppo, and a voucher (No. 06137) was deposited in the Herbarium of the Departamento de Biologia of Universidade Federal do Sergipe (UFS), city of São Cristovão (Sergipe State, Brazil).

Isolation and identification of $\alpha, \beta$-amyrin

The leaves $(1.30 \mathrm{~kg})$ were dried on shadow, and then were powdered and extracted with methanol for $36 \mathrm{~h}$. The obtained filtrate was concentrated under reduced pressure in a rotary evaporator at $40{ }^{\circ} \mathrm{C}$, which yielded $7.35 \mathrm{~g}$ of extract. The methanolic extract was partitioned with hexane/MeOH: $\mathrm{H}_{2} \mathrm{O}$ (9:1), $\mathrm{CHCl}_{3} / \mathrm{MeOH}: \mathrm{H}_{2} \mathrm{O}$ (6:4) and EtOAc/ $\mathrm{H}_{2} \mathrm{O}$. The hexanic extract $(5.35 \mathrm{~g}$ ) was submitted to a filtration $\mathrm{CC}$ in silica-gel 60 using hexane/EtOAc in a growing order of polarity as mobile phase. The fractions were grouped by comparative TLC and submitted to new chromatographic partition. The mixture of $\alpha, \beta$-amyrin $(835.0 \mathrm{mg})$ was isolated from the fraction eluted with hexane/EtOAc (8:2). These compounds had their structures elucidated by analysis of the NMR data $\left({ }^{1} \mathrm{H},{ }^{13} \mathrm{C}\right.$, polarization transfers (DEPT $90^{\circ}$ and DEPT $135^{\circ}$ ), heteronuclear multiple-quantum correlation spectroscopy (HMQC) and heteronuclear multiple bond correlation (HMBC)) and by comparison with literature data. ${ }^{2}$ 
Synthesis of 3-bromoacetyl- $\alpha, \beta$-amyrin esters $(\mathbf{2 a} \mathbf{a}, \mathbf{b})$

The mixture of $\alpha, \beta$-amyrin $(\mathbf{1 a}, \mathbf{b})(100 \mathrm{mg}$, $0.24 \mathrm{mmol}$ ) was dissolved in $5 \mathrm{~mL}$ of $\mathrm{CHCl}_{3}$ in the presence of anhydrous $\mathrm{K}_{2} \mathrm{CO}_{3}$. After completely dissolving, bromoacetyl bromide $(73.5 \mathrm{mg}, 0.36 \mathrm{mmol})$ was added at room temperature and the mixture was stirred for $24 \mathrm{~h}$ in inert atmosphere. Then, the reaction mixture was evaporated and the resulting solid was chromatographed on a silica gel column eluted with $\mathrm{CHCl}_{3}: \mathrm{MeOH}(95: 5)$ to afford compound $\mathbf{2 a}, \mathbf{b}$ in $85 \%$ yield; FTIR $(\mathrm{KBr}) \mathrm{v} / \mathrm{cm}^{-1}$ 2947, 2924, 2904, 2866, 2823, 1751, 1458, 1381, 1168; ${ }^{1} \mathrm{H}$ NMR $\left(500 \mathrm{MHz}, \mathrm{CDCl}_{3}\right) \delta 0.71(\mathrm{~s}, 3 \mathrm{H}, \mathrm{H}-25), 0.74$ (s, 3H, H-24), 0.80 (d, 3H, J 11.6 Hz, H-5), 0.80 (d, 3H, $J 7.0 \mathrm{~Hz}, \mathrm{H}-30), 0.88$ (d, 3H, J 6.0 Hz, H-29), 0.89 (s, 3H, $\mathrm{H}-26), 0.93$ (s, 3H, H-28), 1.02 (s, 6H, H-23 and H-28), 1.78 $(\mathrm{td}, 2 \mathrm{H}, J 5.0$ and $13.5 \mathrm{~Hz}, \mathrm{H}-16), 1.88(\mathrm{dt}, 2 \mathrm{H}, J 3.0$ and $7.0 \mathrm{~Hz}, \mathrm{H}-22), 1.92$ (td, $1 \mathrm{H}, J 4.5$ and $13.5 \mathrm{~Hz}, \mathrm{H}-15), 1.94$ (dd, $1 \mathrm{H}, J 4.0$ and $13.7 \mathrm{~Hz}, \mathrm{H}-18$ ), 3.82 (d, $1 \mathrm{H}, J 15.0 \mathrm{~Hz}$, H-2'), 3.84 (d, 1H, J 15.0 Hz, H-2'), 4.58 (m, 1H, H-3), 5.14 (t, 1H, J 5.0 Hz, H-12), 5.19 (t, J $5.0 \mathrm{~Hz}, \mathrm{H}-12$ ); ${ }^{13} \mathrm{C} \mathrm{NMR}\left(125 \mathrm{MHz}, \mathrm{CDCl}_{3}\right) \delta 38.4(\mathrm{C}-1), 28.8(\mathrm{C}-2), 83.3$ (C-3), 38.9/38.7 (C-4), 55.3 (C-5), 18.3 (C-6), 32.5/32.4 (C-7), 39.8/38.9 (C-8), 47.6 (C-9), 37.2 (C-10), 23.3/23.4 (C-11), 124.2/121.6 (C-12), 139.7/145.2 (C-13), 42.1/41.7 (C14), 26.9/26.3 (C-15), 26.6/26.2 (C-16), 33.3/32.5 (C17), 59.1/47.6 (C-18), 39.7/46.8 (C-19), 39.7/31.3 (C-20), 31.1/34.7 (C-21), 41.7/37.1 (C-22), 28.1 (C-23),15.7/15.5 (C-24), 15.7/15.5 (C-25), 16.9 (C-26), 23.3/26.9 (C-27), 28.1/28.8 (C-28), 17.5/33.7 (C-29), 21.4/23.3 (C-30), 167.1 (C-1'), 28.0 (C-2').

General procedure to synthesis of $\alpha$-aminoacetyl- $\alpha, \beta$-amyrin esters (3-9a,b)

$0.10 \mathbf{m m o l}$ of $\boldsymbol{\alpha}$-bromoesters $\mathbf{2} \mathbf{a}, \mathbf{b}$ was dissolved in $5 \mathrm{~mL}$ of $\mathrm{MeCN}$ and mixed until complete dissolution. After, $0.30 \mathrm{mmol}$ of amine was added to solution. The reaction proceeded for $24 \mathrm{~h}$ at room temperature under inert atmosphere. The reaction product was concentrated under vacuum and the resulting white solid was chromatographed on a silica gel column eluted with $\mathrm{CHCl}_{3}: \mathrm{MeOH}$ (9:1). For imidazole derivative, DMF was employed as solvent to lead 9a,b.

$\alpha$-Diethylaminoacetyl- $\alpha, \beta$-amyrin esters (3a,b)

Yield: 77\%; FTIR (KBr) v / cm ${ }^{-1} 2970,2947,2924$, 2850, 1732, 1458, 1388, 1184, 1145; ${ }^{1} \mathrm{H}$ NMR $(500 \mathrm{MHz}$, $\left.\mathrm{CDCl}_{3}\right) \delta 0.71$ (s, 3H, H-25), 0.73 (s, 3H, H-24), 0.80 (d, $3 \mathrm{H}, J 7.0 \mathrm{~Hz}, \mathrm{H}-30), 0.81$ (d, 3H, J $11.6 \mathrm{~Hz}, \mathrm{H}-5), 0.89$ (s, 3H, H-26), 0.90 (d, 3H, J 6.0 Hz, H-29), 0.94 (s, 3H, $\mathrm{H}-28), 1.02$ (s, 6H, H-23 and H-27), 1.09 (t, 3H, J $5.0 \mathrm{~Hz}$, H-2a"), 1.09 (t, 3H, J 5.0 Hz, H-2b"), 1.80 (td, 2H, J 5.0 and 13.5 Hz, H-16), 1.89 (dt, 2H, J 3.0 and $7.0 \mathrm{~Hz}, \mathrm{H}-22$ ), 1.92 (td, $1 \mathrm{H}, J 4.5$ and $13.5 \mathrm{~Hz}, \mathrm{H}-15), 1.93$ (dd, 1H, J 4.0 and $13.7 \mathrm{~Hz}, \mathrm{H}-18), 2.70$ (q, 4H, $J 5.0 \mathrm{~Hz}, \mathrm{H}-1 \mathrm{a}$ " and H-1b"), 3.36 (s, 2H, H-2'), 4.58 (m, 1H, H-3), 5.14 (t, 1H, $J 5.0 \mathrm{~Hz}, \mathrm{H}-12), 5.19$ (t, 1H, J 5.0 Hz, H-12); ${ }^{13} \mathrm{C}$ NMR $\left(125 \mathrm{MHz}, \mathrm{CDCl}_{3}\right) \delta 37.8(\mathrm{C}-1), 28.9(\mathrm{C}-2), 81.1(\mathrm{C}-3)$, 38.8/38.7 (C-4), 55.3/54.1 (C-5), 18.3 (C-6), 32.3 (C-7), 39.7/38.2 (C-8), 47.7/47.2 (C-9), 37.8 (C-10), 23.7/23.6 (C-11), 124.4/121.7 (C-12), 139.7/145.2 (C-13), 41.7/41.6 (C-14), 27.9/26.7 (C-15), 26.8/26.1 (C-16), 33.9/32.6 (C-17), 59.1 (C-18), 39.7/47.6 (C-19), 39.7/31.1 (C-20), 31.0/34.8 (C-21), 41.6/37.8 (C-22), 28.1 (C-23), 15.7/15.4 (C-24), 15.7/15.4 (C-25), 16.9 (C-26), 23.7/26.7 (C-27), 28.1/28.8 (C-28), 18.3/33.8 (C-29), 21.4/23.5 (C-30), 171.3 (C-1'), 47.6/46.9 (C-2'), 47.8 (C-1a'), 47.8 (C-1b'), 12.4 (C-2a'), 12.4 (C-2b'); ESI-HRMS m/z 540.48011 (observed), 540.47806 (required for $[\mathrm{M}+\mathrm{H}]^{+}$).

\section{$\alpha$-Piperydinoacetyl- $\alpha, \beta$-amyrin esters $(\mathbf{4 a}, \mathbf{b})$}

Yield: 80\%; FTIR (KBr) $v / \mathrm{cm}^{-1} 2932,2855,1743$, $1458,1392,1188,1130 ;{ }^{1} \mathrm{H} \mathrm{NMR}\left(500 \mathrm{MHz}, \mathrm{CDCl}_{3}\right) \delta 0.71$ (s, 3H, H-25), 0.73 (s, 3H, H-24), 0.81 (d, 3H, J $11.6 \mathrm{~Hz}$, H-5), 0.81 (d, 3H, J 7.0 Hz, H-30), 0.88 (d, 3H, J $6.0 \mathrm{~Hz}$, H-29), 0.89 (s, 3H, H-26), 0.93 (s, 3H, H-28), 1.02 (s, 6H, H-23 and H-27), 1.44 (s, 2H, H-4"), 1.55 (s, 2H, H-3"), 1.55 (s, 2H, H-6"), 1.78 (td, 2H, J 5.0 and $13.5 \mathrm{~Hz}, \mathrm{H}-16$ ), $1.91(\mathrm{dt}, 2 \mathrm{H}, J 3.0$ and $7.0 \mathrm{~Hz}, \mathrm{H}-22), 1.92$ (td, $1 \mathrm{H}, J 4.5$ and $13.5 \mathrm{~Hz}, \mathrm{H}-15), 1.94$ (dd, $1 \mathrm{H}, J 4.0$ and $13.7 \mathrm{~Hz}, \mathrm{H}-18$ ), 2.54 (s, 4H, H-2" and H-6"), 3.20 (s, 2H, H-2'), 4.58 (m, $1 \mathrm{H}, \mathrm{H}-3), 5.13$ (t, 1H, J $5.0 \mathrm{~Hz}, \mathrm{H}-12$ ), 5.19 (t, 1H, J $5.0 \mathrm{~Hz}$, $\mathrm{H}-12) ;{ }^{13} \mathrm{C}$ NMR $\left(125 \mathrm{MHz}, \mathrm{CDCl}_{3}\right) \delta 37.7$ (C-1), 28.8 (C-2), 81.1 (C-3), 38.8/38.7 (C-4), 55.2 (C-5), 18.3 (C-6), 32.5/32.2 (C-7), 39.6/38.9 (C-8), 47.6/47.2 (C-9), 37.7 (C-10), 23.5/23.4 (C-11), 124.3/121.6 (C-12), 139.6/145.2 (C-13), 41.7/41.6 (C-14), 27.9/26.3 (C-15), 26.7/26.2 (C-16), 33.7/32.9 (C-17), 60.4/59.1 (C-18), 39.7/47.2 (C-19), 39.6/31.0 (C-20), 31.0/34.7 (C-21), 41.7/37.7 (C-22), 28.1 (C-23), 15.7/15.5 (C-24), 15.7/15.5 (C-25), 16.4 (C-26), 23.1/26.7 (C-27), 28.1/28.8 (C-28), 17.5/33.7 (C-29), 21.5/23.5 (C-30), 170.5 (C-1'), 47.5/46.8 (C-2'), 54.1 (C-2”), 25.8 (C-3"), 24.0 (C-4”), 25.8 (C-5”), 54.1 (C-6"); ESI-HRMS m/z, 540.47908 (observed), 540.47806 (required for $[\mathrm{M}+\mathrm{H}]^{+}$).

\section{$\alpha$-Morpholinoacetyl- $\alpha, \beta$-amyrin esters $(\mathbf{5} \mathbf{a}, \mathbf{b})$}

Yield: 99\%; FTIR (KBr) v / cm-1 2947, 2924, 2854, 1743, 1454, 1381, 1188, 1165; ${ }^{1} \mathrm{H}$ NMR $(500 \mathrm{MHz}$, $\left.\mathrm{CDCl}_{3}\right) \delta 0.71(\mathrm{~s}, 3 \mathrm{H}, \mathrm{H}-25), 0.74(\mathrm{~s}, 3 \mathrm{H}, \mathrm{H}-24), 0.80$ (d, 3H, J $11.6 \mathrm{~Hz}, \mathrm{H}-5), 0.80$ (d, 3H, J 7.0 Hz, H-30), 0.88 (d, 3H, J 6.0 Hz, H-29), 0.88 (s, 3H, H-26), 0.93 (s, $3 \mathrm{H}, \mathrm{H}-28), 1.02$ (s, 6H, H-23 and H-27), 1.79 (td, 2H, 
$J 5.0$ and $13.5 \mathrm{~Hz}, \mathrm{H}-16), 1.89(\mathrm{dt}, 2 \mathrm{H}, J 3.0$ and $7.0 \mathrm{~Hz}$, H-22), 1.92 (td, $1 \mathrm{H}, J 4.5$ and $13.5 \mathrm{~Hz}, \mathrm{H}-15$ ), 1.93 (dd, $1 \mathrm{H}, J 4.0$ and $13.7 \mathrm{~Hz}, \mathrm{H}-18), 2.61$ (t, $4 \mathrm{H}, J 5.0 \mathrm{~Hz}, \mathrm{H}-2^{\prime}$ and H-6"), 3.22 (s, 2H, H-2'), 3.76 (t, 4H, J $5.0 \mathrm{~Hz}, \mathrm{H}-3$ " and $\mathrm{H}-5 "), 4.59(\mathrm{~m}, 1 \mathrm{H}, \mathrm{H}-3), 5.14(\mathrm{t}, 1 \mathrm{H}, J 5.0 \mathrm{~Hz}$, $\mathrm{H}-12), 5.19$ (t, 1H, J 5.0 Hz, H-12); ${ }^{13} \mathrm{C}$ NMR $(125 \mathrm{MHz}$, $\mathrm{CDCl}_{3}$ ) $\delta 38.4(\mathrm{C}-1), 28.7$ (C-2), 81.4 (C-3), 38.8/38.7 (C-4), 55.2 (C-5), 18.2 (C-6), 32.5/32.2 (C-7), 39.6/38.9 (C-8), 47.6/47.2 (C-9), 37.7 (C-10), 23.1/23.4 (C-11), 124.3/121.6 (C-12), 139.6/145.2 (C-13), 41.5/41.7 (C-14), 28.1/26.6 (C-15), 26.9/26.1 (C-16), 33.1 (C-17), 59.8/59.1 (C-18), 39.6/47.0 (C-19), 39.5/31.1 (C-20), 31.0/34.7 (C-21), 41.5/37.4 (C-22), 28.2 (C-23), 15.7/15.5 (C-24), 15.7/15.5 (C-25), 16.7 (C-26), 23.2/26.6 (C-27), 28.2/28.7 (C-28), 17.5/33.3 (C-29), 21.4/23.1 (C-30), 169.9 (C-1'), 47.5/46.8 (C-2'), 53.3 (C-2”), 66.8 (C-3”), 66.8 (C-5”), 53.3 (C-6"); ESI-HRMS m/z 554.45835 (observed), 554.45732 (required for $[\mathrm{M}+\mathrm{H}]^{+}$).

\section{$\alpha$-Pyrrolidinoacetyl- $\alpha, \beta$-amyrin esters $(6 \mathbf{a}, \mathbf{b})$}

Yield: 99\%; FTIR (KBr) v / $\mathrm{cm}^{-1}$ 2947, 2924, 2854 , 1739, 1458, 1381, 1184, 1145; ${ }^{1} \mathrm{H}$ NMR $(500 \mathrm{MHz}$, $\left.\mathrm{CDCl}_{3}\right) \delta 0.71$ (s, 3H, H-25), 0,73 (s, 3H, H-24), 0.81 (d, $3 \mathrm{H}, J 11.6 \mathrm{~Hz}, \mathrm{H}-5), 0.81$ (d, 3H, J 7.0 Hz, H-30), 0.87 (d, 3H, J 6.0 Hz, H-29), 0.89 (s, 3H, H-26), 0.95 (s, 3H, $\mathrm{H}-28), 1.02$ (s, 6H, H-23 and H-27), 1.80 (td, 2H, J 5.0 and $13.5 \mathrm{~Hz}, \mathrm{H}-16), 1.88$ (dt, 2H, $J 3.0$ and $7.0 \mathrm{~Hz}, \mathrm{H}-22), 1.91$ (td, $1 \mathrm{H}, J 4.5$ and $13.5 \mathrm{~Hz}, \mathrm{H}-15), 1.91(4 \mathrm{H}, \mathrm{m}, \mathrm{H}-3$ " and H-4"), 1.94 (dd, 1H, J 4.0 and $13.7 \mathrm{~Hz}, \mathrm{H}-18), 2.86$ (4H, t, $J 5.0 \mathrm{~Hz}, \mathrm{H}-2$ " and H-5”) 3.50 (s, 2H, H-2'), 4.61 (m, 1H, $\mathrm{H}-3), 5.13$ (t, 1H, J 5.0 Hz, H-12), 5.19 (t, 1H, J 5.0 Hz, $\mathrm{H}-12) ;{ }^{13} \mathrm{C}$ NMR $\left(125 \mathrm{MHz}, \mathrm{CDCl}_{3}\right) \delta 38.4(\mathrm{C}-1), 28.7$ (C-2), 81.8 (C-3), 38.9/38.7 (C-4), 55.3 (C-5), 18.3 (C-6), 32.5/32.4 (C-7), 39.8/38.4 (C-8), 47.6/47.2 (C-9), 37.1 (C-10), 23.3/23.4 (C-11), 124.3/121.6 (C-12), 139.6/145.2 (C-13), 42.1/41.7 (C-14), 26.9/26.2 (C-15), 26.6/26.0 (C-16), 33.3/32.5 (C-17), 59.1 (C-18), 39.6/46.8 (C-19), 39.8/31.2 (C-20), 31.1/34.7 (C-21), 41.7/37.1 (C-22), 28.1 (C-23), 15.7/15.5 (C-24), 15.7/15.5 (C-25), 16.8 (C-26), 23.3/26.9 (C-27), 28.1/28.7 (C-28), 17.5/33.3 (C-29), 21.4/23.4 (C-30), 169.5 (C-1'), 47.6/46.8 (C-2'), 53.6 (C-2"), 24.0 (C-3"), 24.0 (C-4”), 53.6 (C-5"); ESI-HRMS $\mathrm{m} / \mathrm{z} 538.46190$ (observed), 538.46241 (required for $\left.[\mathrm{M}+\mathrm{H}]^{+}\right)$.

\section{$\alpha$-Anilinoacetyl- $\alpha, \beta$-amyrin esters $(\mathbf{7 a}, \mathbf{b})$}

Yield: 71\%; FTIR (KBr) v / $\mathrm{cm}^{-1} 3395,2924,2854$, $1724,1616,1512,1508,1450,1381,1172 ;{ }^{1} \mathrm{H}$ NMR (500 MHz, $\left.\mathrm{CDCl}_{3}\right) \delta 0.71$ (s 3H, H-25), 0.75 (s, 3H, H-24), 0.81 (d, 3H, J $11.6 \mathrm{~Hz}, \mathrm{H}-5), 0.81$ (d, 3H, J 7.0 Hz, H-30), 0.87 (d, 3H, J 6.0 Hz, H-29), 0.88 (s, 3H, H-26), 0.93 (s,
$3 \mathrm{H}, \mathrm{H}-28$ ), 1.02 (s, 6H, H-23 and H-27), 1.78 (td, 2H, J 5.0 and $13.5 \mathrm{~Hz}, \mathrm{H}-16), 1.87$ (dt, 2H, $J 3.0$ and $7.0 \mathrm{~Hz}, \mathrm{H}-22)$, $1.92(\mathrm{td}, 1 \mathrm{H}, J 4.5$ and $13.5 \mathrm{~Hz}, \mathrm{H}-15), 1.92(\mathrm{dd}, 1 \mathrm{H}, J 4.0$ and $13.7 \mathrm{~Hz}, \mathrm{H}-18), 3.92\left(\mathrm{~m}, 2 \mathrm{H}, \mathrm{H}-2^{\prime}\right), 4.63(\mathrm{~m}, 1 \mathrm{H}$, H-3), 5.14 (t, 1H, J $5.0 \mathrm{~Hz}, \mathrm{H}-12), 5.19$ (t, 1H, J $5.0 \mathrm{~Hz}$, $\mathrm{H}-12), 6.64$ (d, 2H, J 5.0 Hz, H-2" and H-6"), 6.77 (t, 1H, $J 5.0 \mathrm{~Hz}, \mathrm{H}-4$ "), 7.19 (t, 2H, J 5.0 Hz, H-3" and H-15"); ${ }^{13} \mathrm{C} \mathrm{NMR}\left(125 \mathrm{MHz}, \mathrm{CDCl}_{3}\right) \delta 38.5(\mathrm{C}-1), 28.7$ (C-2), 82.3 (C-3), 38.9/38.7 (C-4), 55.3 (C-5), 18.3 (C-6), 32.5/32.4 (C-7), 39.6/38.9 (C-8), 47.6/47.2 (C-9), 37.8 (C-10), 23.3/23.4 (C-11), 124.3/121.6 (C-12), 139.7/145.1 (C-13), 42.1/41.5 (C-14), 26.9/26.2 (C-15), 26.6/26.1 (C-16), 33.3/32.5 (C-17), 59.1 (C-18), 39.7/46.9 (C-19), 39.7/31.3 (C-20), 34.6/34.7 (C-21), 41.5/37.1 (C-22), 28.1 (C-23), 15.7/15.5 (C-24), 15.7/15.5 (C-25), 16.7 (C-26), 23.3/23.9 (C-27), 28.1/28.7 (C-28), 17.5/33.8 (C-29), 21.4/23.3 (C-30), 170.1 (C-1'), 46.8/46.1 (C-2'), 147.1 (C-1'), 113.0 (C-2"), 129.3 (C-3"), 118.2 (C-4"), 129.3 (C-5"), 113.0 (C-6"); ESI-HRMS m/z 582.42868 (observed), 582.42870 (required for $[\mathrm{M}+\mathrm{Na}]^{+}$).

\section{$\alpha$-Benzylaminoacetyl- $\alpha, \beta$-amyrin esters (8a,b)}

Yield: 86\%; FTIR (KBr) v / cm ${ }^{-1} 3300,3030,2947$, 2924, 2854, 1732, 1458, 1377, 1188, 1138; ${ }^{1} \mathrm{H}$ NMR ( $500 \mathrm{MHz}, \mathrm{CDCl}_{3}$ ) $\delta 0.71$ (s, 6H, H-24 and H-25), 0.80 (d, $3 \mathrm{H}, J 7.0 \mathrm{~Hz}, \mathrm{H}-30), 0.81$ (d, 3H, J 11.6 Hz, H-5), 0.88 (d, $3 \mathrm{H}, J 6.0 \mathrm{~Hz}, \mathrm{H}-29), 0.89$ (s, 3H, H-26), 0.93 (s, 3H, H-28), 0.98 (s, 3H, H-27), 1.02 (s, 3H, H-23), 1.78 (td, 2H, J 5.0 and $13.5 \mathrm{~Hz}, \mathrm{H}-16), 1.88$ (dt, $2 \mathrm{H}, J 3.0$ and $7.0 \mathrm{~Hz}, \mathrm{H}-22$ ), $1.92(\mathrm{td}, 1 \mathrm{H}, J 4.5$ and $13.5 \mathrm{~Hz}, \mathrm{H}-15), 1.94$ (dd, $1 \mathrm{H}, J 4.0$ and $13.7 \mathrm{~Hz}, \mathrm{H}-18$ ), 3.44 (s, 2H, H-2'), 3.87 (s, 2H, H-4'), $4.60(\mathrm{~m}, 1 \mathrm{H}, \mathrm{H}-3), 5.14(\mathrm{t}, 1 \mathrm{H}, J 5.0 \mathrm{~Hz}, \mathrm{H}-12), 5.20(\mathrm{t}, 1 \mathrm{H}$, J $5.0 \mathrm{~Hz}, \mathrm{H}-12), 7.36$ (m, 5H, Ph); ${ }^{13} \mathrm{C}$ NMR (125 MHz, $\left.\mathrm{CDCl}_{3}\right) \delta 38.2$ (C-1), 28.8 (C-2), 81.9 (C-3), 38.9/38.7 (C-4), 55.3/49.9 (C-5), 18.3 (C-6), 32.6/32.4 (C-7), 39.8/38.9 (C-8), 47.7/47.2 (C-9), 37.3 (C-10), 23.3/23.4 (C-11), 124.3/121.6 (C-12), 139.6/145.2 (C-13), 42.1/41.7 (C-14), 26.9/26.4 (C-15), 26.6/26.2 (C-16), 33.8/32.5 (C-17), 59.1 (C-18), 39.7/46.8 (C-19), 40.0/31.2 (C-20), 31.1/34.7 (C-21), 41.7/37.2 (C-22), 28.2 (C-23), 15.7/15.6 (C-24), 15.7/15.6 (C-25), 16.8 (C-26), 23.3/26.9 (C-27), 28.1/28.8 (C-28), 17.2/33.7 (C-29), 21.4/23.5 (C-30), 171.7 (C-1'), 47.6/46.8 (C-2'), 53.1 (C-4'), 138.6 (C-1'), 128.5 (C-2"), 128.5 (C-3"), 127.4 (C-4”), 128.5 (C-5”), 128.5 (C-6"); ESI-HRMS m/z 574.46395 (observed), 574.46241 (required for $[\mathrm{M}+\mathrm{H}]^{+}$).

\section{$\alpha$-Imidazoacetyl- $\alpha, \beta$-amyrin esters $(\mathbf{9 a}, \mathbf{b})$}

Yield: 54\%; FTIR (KBr) $v / \mathrm{cm}^{-1}$ 2945, 2850, 1746, 1619, $1465,1380,1221 ;{ }^{1} \mathrm{H}$ NMR $\left(500 \mathrm{MHz}, \mathrm{CDCl}_{3}\right) \delta 0.70(\mathrm{~s}, 3 \mathrm{H}$, H-25), 0.75 (s, 3H, H-24), 0.80 (d, 3H, J 11.6 Hz, H-5), 0.80 
(d, 3H, J 7.0 Hz, H-30), 0.88 (d, 3H, J6.0 Hz, H-29), 0.89 (s, $3 \mathrm{H}, \mathrm{H}-26), 0.93$ (s, 3H, H-28), 1.01 (s, 6H, H-23 and H-27), $1.78(\mathrm{td}, 2 \mathrm{H}, J 5.0$ and $13.5 \mathrm{~Hz}, \mathrm{H}-16), 1.86(\mathrm{dt}, 2 \mathrm{H}, J 3.0$ and $7.0 \mathrm{~Hz}, \mathrm{H}-22), 1.92$ (td, $1 \mathrm{H}, J 4.5$ and $13.5 \mathrm{~Hz}, \mathrm{H}-15$ ), 1.93 (dd, $1 \mathrm{H}, J 4.0$ and $13.7 \mathrm{~Hz}, \mathrm{H}-18), 4.59$ (m, $1 \mathrm{H}, \mathrm{H}-3$ ), 4.70 (s, 2H, H-2'), 5.14 (t, 1H, J 5.0 Hz, H-12), 5.18 (t, 1H, J 5.0 Hz, H-12), 6.96 (s, 1H, H-5"), 7.11 (s, 1H, H-4"), 7.53 (s, 1H, H-2"); ${ }^{13} \mathrm{C}$ NMR $\left(125 \mathrm{MHz}, \mathrm{CDCl}_{3}\right) \delta 38.2(\mathrm{C}-1)$, 28.8 (C-2), 83.5 (C-3), 38.9/38.7 (C-4), 55.2 (C-5), 18.3 (C-6), 39.5/32.4 (C-7), 39.6/38.9 (C-8), 47.6/47.3 (C-9), 37.8 (C-10), 23.5/23.6 (C-11), 124.2/121.6 (C-12), 139.7/145.3 (C-13), 42.1/41.8 (C-14), 26.9/26.3 (C-15), 26.6/26.2 (C-16), 33.2/32.9 (C-17), 59.1 (C-18), 39.6/46.8 (C-19), 39.7/31.3 (C-20), 31.1/34.7 (C-21), 41.7/37.1 (C-22), 28.1 (C-23), 15.7/15.5 (C-24), 15.7/15.5 (C-25), 16.7 (C-26), 23.4/26.9 (C-27), 28.1/28.8 (C-28), 17.5/33.3 (C-29), 21.4/23.5 (C-30), 167.0 (C-1'), 47.7/46.9 (C-2'), 137.9 (C-2”), 129.7 (C-4"), 119.9 (C-5"); ESI-HRMS m/z 535.42705 (observed), 535.42635 (required for $[\mathrm{M}+\mathrm{H}]^{+}$).

\section{Biological assays}

The cytotoxicity was tested against HL-60 (human leukemia), HCT-116 (human colon) and PC-3 (human prostate) cancer cell-lines obtained from the National Cancer Institute, Bethesda (MD, USA). Cells were cultured in RPMI-1640 medium supplemented with $10 \%$ fetal bovine serum, $1 \%$ antibiotics and incubated at $37^{\circ} \mathrm{C}$ under a $5 \% \mathrm{CO}_{2}$ atmosphere. The cytotoxicity of the samples was assessed by the MTT method. For experiments, cells were seeded in 96 -well plates $(0.7 \times 105$ for adherent cells or $0.3 \times 106$ for suspended cells in $100 \mathrm{~mL}$ medium). The compounds $\left(5 \mu \mathrm{g} \mathrm{m}^{-1}\right)$ dissolved in DMSO 5\% (dimethyl sulfoxide) were added to each well (using the high-throughput screening (HTS), Biomek 3000, Beckman Coulter, Inc. Fullerton, California, USA) and incubated for 3 days ( $72 \mathrm{~h}$ ). After $69 \mathrm{~h}$ of incubation, the supernatant was replaced by fresh medium containing MTT $\left(0.5 \mathrm{mg} \mathrm{mL}^{-1}\right)$. After $3 \mathrm{~h}$, the MTT formazan product was dissolved in $150 \mu \mathrm{L}$ of DMSO, and absorbance was measured at $595 \mathrm{~nm}$ (DTX 880 Multimode Detector, Beckman Coulter, Inc. Fullerton, California, USA). Control groups received the same amount of DMSO.

The $\mathrm{IC}_{50}$ values of active samples were determined by MTT assay using increasing concentrations ( 0.2 to $25 \mu \mathrm{g} \mathrm{mL}^{-1}$ ) against HL-60, HCT-116 and PC-3 cell-lines after $72 \mathrm{~h}$ of incubation. Doxorubicin (Dox) was used as positive control. Control groups received the same amount of DMSO. The $\mathrm{IC}_{50}$ values and their $95 \%$ confidence intervals (CI 95\%) were obtained by non-linear regression using the GraphPad Software 5.0.

\section{Supplementary Information}

Supplementary data (IR, ${ }^{1} \mathrm{H}$ and ${ }^{13} \mathrm{C}$ NMR spectra and HRMS of compounds 2-9a, b) are available free of charge at http://jbcs.sbq.org.br as PDF file.

\section{Acknowledgments}

This research received financial support from FAPESB and CNPq. The authors thank National Cancer Institute (Bethesda, MD, USA) for donating the tumor cells used in this study, LABAREMN (UFBA) for conducting NMR analyses and F. N. Santos and M. N. Eberlin (Unicamp) for the HRMS analyses.

\section{References}

1. World Health Organization, http://www.who.int/cancer/en/, accessed in March 2017.

2. Vazquez, L. H.; Palazon, J.; Navarro-Ocaña, A. In Phytochemicals - A Global Perspective of their Role in Nutrition and Health; Rao, V., ed.; InTech: Croatia, 2012, ch. 23, p. 487-502.

3. Melo, C. M.; Morais, T. C.; Tome, A. R.; Brito, G. A. C.; Chaves, M. H.; Rao, V. S.; Santos, F. A.; Inflammation Res. 2011, 60, 673.

4. Otuki, M. F.; Vieira-Lima, F.; Malheiros, K.; Yunes, R. A.; Calixto, J. B.; Eur. J. Pharmacol. 2005, 507, 253.

5. Matos, I.; Bento, A. F.; Marcon, R.; Claudino, R. F.; Calixto, J. B.; Mol. Immunol. 2013, 54, 482.

6. Melo, C. M.; Carvalho, K. M. M. B.; Neves, J. C. S.; Morais, T. C.; Rao, V. S.; Santos, F. A.; Brito, G. A. B.; Chaves, M. H.; World J. Gastroenterol. 2010, 16, 4272.

7. Aragão, G. F.; Christiany, C. P.; Bandeira, P. N.; Lemos, T. L. G.; Viana, G. S. B.; J. Herbal Pharmacother. 2008, 7, 31.

8. Soldi, C.; Pizzolatti, M. G.; Luiz, A. P.; Marcon, R.; Meotti, F. C.; Mioto, L. A.; Santos, A. R. S.; Bioorg. Med. Chem. 2008, 16, 3377.

9. Kannan, S.; Vijayakumar, B.; Sureshkumar, C.; Mohankumar, R.; Narasimhan, S.; Asian J. Chem. 2013, 25, 1167.

10. Chenniappan, K.; Kadarkari, M.; Parasitol. Res. 2012, 110, 2117.

11. Aragão, G. F.; Carneiro, L. M. V.; Junior, A. P. F.; Vieira, L. C.; Bandeira, P. N.; Lemos, T. L. G.; Viana, G. S. D.; Pharmacol. Biochem. Behav. 2006, 85, 827.

12. Kweifiookai, G.; Demunk, F.; Rumble, B. A.; Macrides, T. A.; Cropley, M.; Res. Commun. Mol. Pathol. Pharmacol. 1994, 85, 45.

13. Oliveira, F. A.; Vieira-Junior, G. M.; Chaves, M. H.; Almeida, F. R. C.; Santos, K. A.; Martins, F. S.; Silva, R. M.; Santos, F. A.; Rao, V. S. N.; Planta Med. 2004, 70, 780.

14. Narender, T.; Khaliq, T.; Singh, A. B.; Joshi, M. D.; Mishra, P.; Chaturvedi, J. P.; Srivastava, A. K.; Maurya, R.; Agarwal, S. C.; Eur. J. Med. Chem. 2009, 44, 1215. 
15. Rosas-Acevedo, H.; Terrazas, T.; González-Trujano M. E.; Guzmán, Y.; Soto-Hernández, M.; J. Ethnopharmacol. 2011, 134, 67.

16. Johann, S.; Soldi, C.; Lyon, J. P.; Pizzolatti, M. G.; Resende, M. A.; Lett. Appl. Microbiol. 2007, 45, 148.

17. Diaz-Ruiz, G.; Hernandez-Vazquez, L.; Luna, H.; Wacher-Rodarte, M. D.; Navarro-Ocana, A.; Molecules 2012, 17, 12603.

18. Aragão, G. F.; Carneiro, L. M. V.; Junior, A. P. F.; Bandeira, P. N.; Lemos, T. L. G.; Viana, G. S. B.; Pharm. Biol. 2007, 45, 343.

19. Lin, K.; Huang, A.; Tu, H.; Lee, L.; Wu, C.; Hour, T.; Yang, S.; Pu., Y.; Lin, C.; J. Agric. Food Chem. 2011, 59, 407.
20. Thao, N. T. P.; Hung, T. M.; Lee, M. K.; Kim, J. C.; Min, B. S.; Bae, K.; Chem. Pharm. Bull. 2010, 58, 121.

21. Barros, F. W. A.; Bandeira, P. N.; Lima, D. J. B.; Meira, A. S.; de Farias, S. S.; Albuquerque, M.; dos Santos, H. S.; Lemos, T. L. G.; de Morais, M. O.; Costa-Lotufo, L. V.; Pessoa, C. D.; Bioorg. Med. Chem. 2011, 19, 1268.

22. Rai, R.; Pandey, P. S.; Bioorg. Med. Chem. Lett. 2005, 15, 2923.

23. Khatri, V. K.; Upetri, S.; Pandey, P. S.; Org. Lett. 2006, 8, 1755. 24. Mossman, T.; J. Immunol. Methods 1983, 65, 55.

Submitted: January 4, 2017 Published online: April 6, 2017 